\title{
ACTION OF HYDROGEN SULFIDE DONORS ON NITROSO-OXIDATIVE PROCESSES IN SMALL INTESTINE OF RATS WITH METHOTREXATE- INDUCED ENTEROPATHY
}

Introduction. Medication-induced enteropathy plays an important part among factors leading to the development of small intestinal injury. There are some evidences indicating a potential preventive action of hydrogen sulfide $\left(\mathrm{H}_{2} \mathrm{~S}\right)$ donors against drug-induced enteropathies based on that fact that the use of the most of enterotoxic medications including anti-tumor drugs leads to the suppression of this gaseous mediator production.

The aim of the study - to compare the action of $\mathrm{H}_{2} \mathrm{~S}$ donors in small intestine of rats on parameters of NOsynthase system and oxidative stress under condition of methotrexate-induced enteropathy.

Research Methods. The experimental procedures were carried out on rats which on the background of methotrexate-induced enteropathy received $\mathrm{H}_{2} \mathrm{~S}$ donors NaHS (1 and $10 \mathrm{mg} / \mathrm{kg}$ ) and L-cysteine. Following biochemical parameters were measured in small intestinal mucosa: activity of NO-synthases, myeloperoxidase, superoxide dismutase and catalase; concentrations of $\mathrm{NO}_{x}$ (nitrite/nitrate) and malonic dialdehyde. $\mathrm{H}_{2} \mathrm{~S}$ concentration was determined in blood serum.

Results and Discussion. Administration of methotrexate didn't cause any visible changes of small intestine surface, however led to serious biochemical changes. NO concentration increased as a result of iNOS activation (more than fivefold $(p \leq 0.01)$. Simultaneously concentration of $\mathrm{H}_{2} \mathrm{~S}$ decreased in blood serum. Administration of $\mathrm{H}_{2} \mathrm{~S}$ donors practically returned these parameters to their normal value. Methotrexate-induced enteropathy caused the increase of myeloperoxidase activity by $66 \%, p \leq 0.01$, indicating of inflammatory process formation and activation of lipid peroxidation. Administration of NaHS didn't cause any serious changes in myeloperoxidase activity, however increased SOD activity and practically retuned it to its norm.

Conclusions. Nirtoso-oxidative stress plays the key role in enteropathy formation resulted in methotrexate administration. $\mathrm{H}_{2} \mathrm{~S}$ donors modulate parameters of $\mathrm{NO}$-synthase system and activity of SOD.

KEY WORDS: enteropathy; methotrexate; hydrogen sulfide; NO-synthases oxidative stress.

INTRODUCTION. Increased toxicity of different medications in the gastrointestinal tract is a common and serious medical problem; the number of drugs that can harm the gastrointestinal tract is impressive [1]. Enteropathy is known to be one of the most commonly appeared pathologies resulting in the use of medications such as: nonsteroidal anti-inflammatory drugs (NSAIDs), anti-tumor drugs and hypotensive medications [2]. Among anti-tumor drugs methotrexate and 5-fluorouracil is known by its ability to damage the small intestinal mucosa by preventing crypt mitotic activity, inhibiting dihydrofolate reductase and leading to the development of malabsorption syndrome and diarrhoea [3]. There are some evidences indicating a potential preventive action of hydrogen sulfide $(\mathrm{H} 2 \mathrm{~S})$ donors against drug-induced enteropathies [2, 4] based on that fact that the use of the most of enterotoxic medications including anti-tumor drugs leads to the suppression (c) Yu. O. Sklyarova, I. S. Fomenko, 2018. of this gaseous mediator production. The most common way to generate $\mathrm{H}_{2} \mathrm{~S}$ for experiments is to use common salts such as NaHS and its precursors such as L-cysteine [5]. Cytoprotective effects of donors of $\mathrm{H}_{2} \mathrm{~S}$ were previously demonstrated on the model of indomethacin-induced small intestinal injury in rats [2, 4]. However, their effects in methotrexate-induced enteropathy are still poorly studied.

The aim of the study - to evaluate the action of $\mathrm{H}_{2} \mathrm{~S}$ donors in small intestine of rats on parameters of NO-synthase system and oxidative stress under condition of methotrexate-induced enteropathy.

RESEARCH METHODS. The structure of this study and the experimental procedures performed on the animals were approved by the Ethical Committee of Lviv National Medical University. The experimental procedures were carried out in accordance with the international guidelines for the use and care of laboratory animals. Male, outbred 
albino rats weighing 200-220 $\mathrm{g}$ were used. Animals were randomly divided into 5 groups: group 1 - intact animals were used as controls; 2 - methotrexate, an anti-tumour drug was introduced in a single dose of $10 \mathrm{mg} / \mathrm{kg}$, intraperitoneally [6] to induce enteropathy; animals in the groups 3,4 and 5 groups received $\mathrm{NaSH}(1 \mathrm{mg} / \mathrm{kg}), \mathrm{NaSH}(10 \mathrm{mg} / \mathrm{kg})$ and L-cysteine were introduced intraperitoneally twice after methotrexate. 3 days after injection of methotrexate enteropathy had developed.

Rats were anesthetized with $1 \mathrm{ml}$ of urethane at a dose of $1.1 \mathrm{mg} / \mathrm{kg}$ injected intraperitoneally and sacrificed by cervical dislocation. A blood sample from the cervical vessel was immediately collected into vials containing $0.1 \mathrm{ml}$ of heparin. The samples of small intestinal mucosa were homogenised in phosphate buffer pH 6.0 1:4 and centrifuged at 3000 rpm, supernatant was used to determine values of biochemical parameters. Activity of NO-synthase isoenzymes (inducible iNOS and constitutive cNOS) was measured by the method described in detail [7]. NOS activity was expressed in nmol L-citrylline/ min $\times$ mg of protein. NOx (nitrite/nitrate) concentration in homogenates of small intestine was assayed by the Griess reaction-dependent method of [8]. In order to determine total $\left(\mathrm{NO}_{2} / \mathrm{NO}_{3}\right)$ concentration to deproteinised homogenates (1:100) of zinc for reduction of nitrate to nitrite or manganese sulphate for measurement of nitrate-anion were added. Naphthyl-ethylenediamine was used to perform Griess reaction. The absorbance was read in a Statfax at 520-560 (550) nm. Concentration of stable products of $\mathrm{NO}$ was expressed as nitrite+nitrate $(\mathrm{mmol} / \mathrm{g})$. Myeloperoxidase (MPO) activity in small intestinal homogenates was assayed spectrophotometrically by the method [9] with some modifications. The MPO activity was analysed spectrophotometrically as follows: $1 \mathrm{ml}$ of homogenate was added to $2.9 \mathrm{ml}$ of $0.1 \mathrm{M} \mathrm{K}_{3} \mathrm{PO}_{4}$ buffer $(\mathrm{pH} 6.0)$ involving O-dianisidine dihydrochloride $(0.167 \mathrm{mg} / \mathrm{ml})$ and $0.005 \%$ hydrogen peroxide of the resection mixture was recorded at a wave length of $450 \mathrm{~nm}$. One unit $(U)$ of activity was defined as that degrading $1 \mu$ mole of peroxide/mg of protein. Lipid peroxidation levels were determined as malonic dialdehyde (MDA) concentration in homogenates of gastric mucosa, according to the procedure [10]. MDA levels were expressed as $\mathrm{mmol} / \mathrm{l}$. Activity of superoxide dismutase (SOD) was determined by the reaction of reduction of nitrotetrazolium blue to nitroformazan [11]. SOD activity was expressed in $\mathrm{mmol} / \mathrm{min} \times \mathrm{mg}$ of protein. Catalase (CAT) activity was determined by measuring of the decrease in hydrogen peroxide concentration at $410 \mathrm{~nm}$ [12]. Catalase activity was expressed in mmol $\mathrm{H}_{2} \mathrm{O}_{2} l$ min $\times$ mg of protein. $\mathrm{H}_{2} \mathrm{~S}$ concentration was determined by reaction with para-phenylenediamine [13].

The statistical processing of the data was done by conventional methods for analysis of variance using MS Excel software for Student's test. The difference was considered to be significant at $p \leq 0.05$.

RESULTS AND DISCUSSION. Administration of methotrexate didn't cause any visible changes of small intestine surface. It should be pointed out that methotrexate-treated animals were suffering from severe enterotoxicosis manifested by diarrhoea and vomiting.

Methotrexate-induced enteropathy was accompanied by significant changes of gaseous mediators production manifested by the decrease of $\mathrm{H}_{2} \mathrm{~S}$ concentration in blood serum by $20 \%(p \leq 0.01)$ and the increase of $\mathrm{NO}_{x}$ concentration in small intestinal mucosa by $40 \%$ ( $\mathrm{p} \leq 0.01$ ) (Fig. 1). In recent years it was shown, that hydrogen sulfide plays an impor-
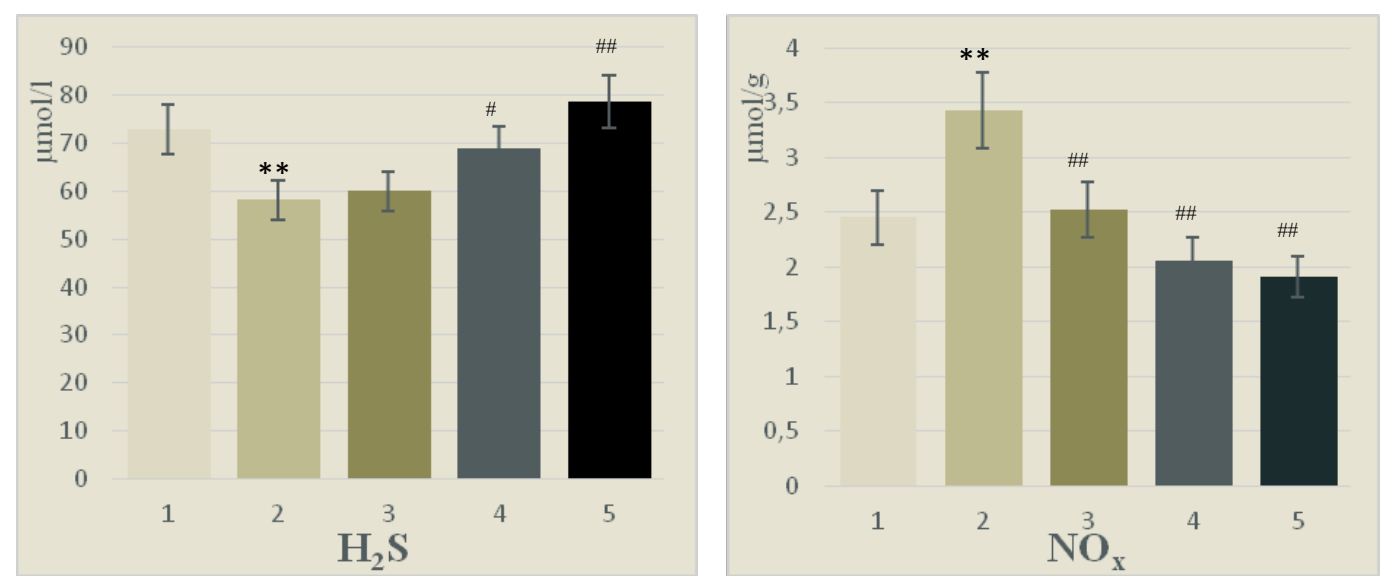

Fig. 1. Concentrations of $\mathrm{H}_{2} \mathrm{~S}$ in blood serum and stable products of $\mathrm{NO}$ in homogenates of small intestinal mucosa at the background of methotrexate-induced enteropathy of rats of the following groups: group 1-control group, group 2 - methotrexate-induced enteropathy, group $3-$ methotrexate $+1 \mathrm{mg} / \mathrm{kg}$ of NaSH , group $4-$ methotrexate $10 \mathrm{mg} / \mathrm{kg} \mathrm{NaSH}$, group $5-$ methotrexate + L-Cys. Mean $\pm S D, n=8$ in each group of animals. ${ }^{*}-p \leq 0.05,{ }^{* *}-p \leq 0.01$, in relation to control animals; ${ }^{*}-p \leq 0.05$, \# $-p \leq 0.01$ as compared to the methotrexate action. 
tant role in promoting resolution of inflammation, and restoration of normal tissue function [14], thus the suppression of its synthesis in medication-induced small intestinal injury may play a crucial role for development of enteropathy.

$\mathrm{H}_{2} \mathrm{~S}$ donor NaHS displayed the tendency to increase of $\mathrm{H}_{2} \mathrm{~S}$ concentration whereas L-cysteine administration returned it to its normal level. $\mathrm{H}_{2} \mathrm{~S}$ donors dose-dependently decreased $\mathrm{NO}_{\mathrm{x}}$ concentration in correspondence to the existence of metabolic relationship between both gaseous mediators.

Changes of $\mathrm{NO}_{x}$ concentration in group of methotrexate-treated animals were resulted by the increase of iNOS activity (more than fivefold ( $\leq \leq 0.01$ ) as compared with induced of control group) (Fig. 2). Simultaneously cNOS activity decease by

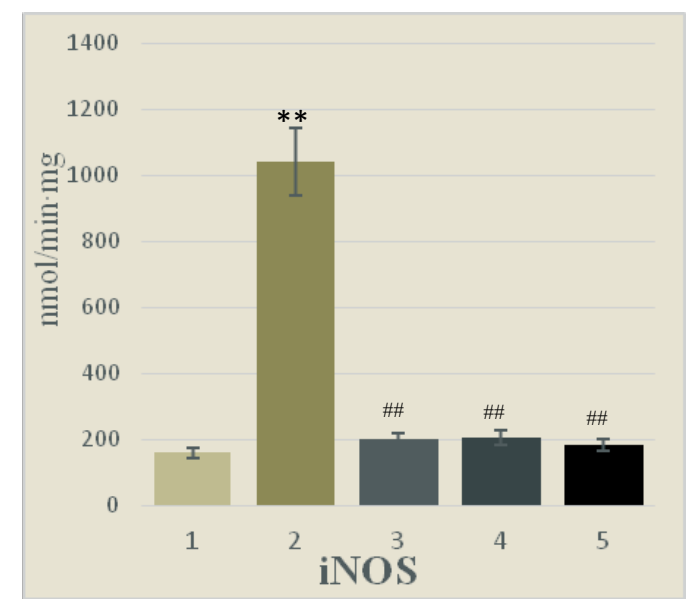

$15 \%(p \leq 0.05)$. All studied inhibitors decreased iNOS activity and practically returned it to its normal levels.

Enterotoxic action of methotrexate was accompanied by the development of oxidative stress in small intestine manifested by the rise of MDA concentration by $61 \%(p \leq 0.01)$ (Fig. 3) and the significant decrease of antioxidant enzyme SOD (Fig. 4). Simultaneously the activity of MPO was increased by $66 \%(p \leq 0.01)$ as compared to the control group which suggests neutrophil infiltration resulting in the development of inflammatory process in small intestine.

None of studied $\mathrm{H}_{2} \mathrm{~S}$ donors decreased MPO activity as compared to methotrexate action. It should be pointed out that ability of hydrogen sulfide to modulate MPO activity was previously shown [15]. However in our study only $\mathrm{H}_{2} \mathrm{~S}$ precursor Lcysteine has demonstrated the tendency to de-

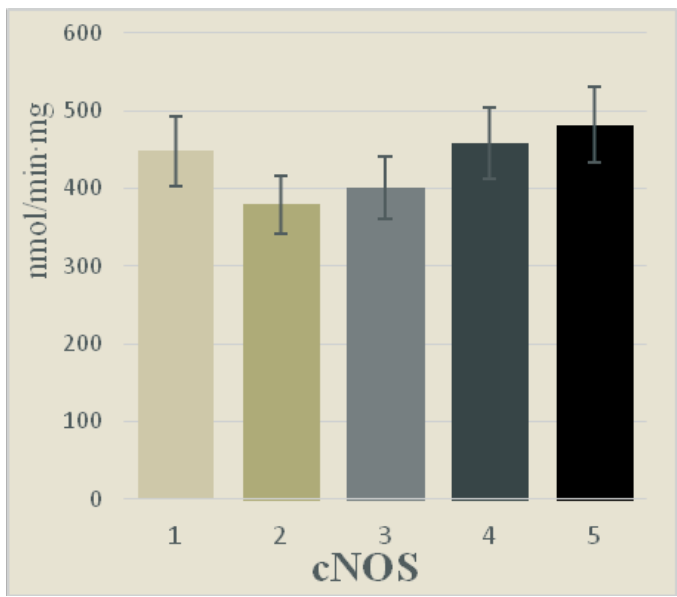

Fig. 2. Activity of nitric oxide synthases (iNOS and cNOS) in homogenates small intestinal mucosa at the background of methotrexate-induced enteropathy of rats of the following groups: group 1 - control group, group 2 - methotrexate-induced enteropathy, group $3-$ methotrexate $+1 \mathrm{mg} / \mathrm{kg}$ of NaSH, group $4-$ methotrexate $+10 \mathrm{mg} / \mathrm{kg} \mathrm{NaSH}$, group $5-$ methotrexate $+\mathrm{L}-$ Cys. Mean $\pm S D, n=8$ in each group of animals. * $-p \leq 0.05,{ }^{*}-p \leq 0.01$, in relation to control animals; ${ }^{*}-p \leq 0.05,{ }^{\#}-p \leq 0.01$ as compared to the methotrexate action.
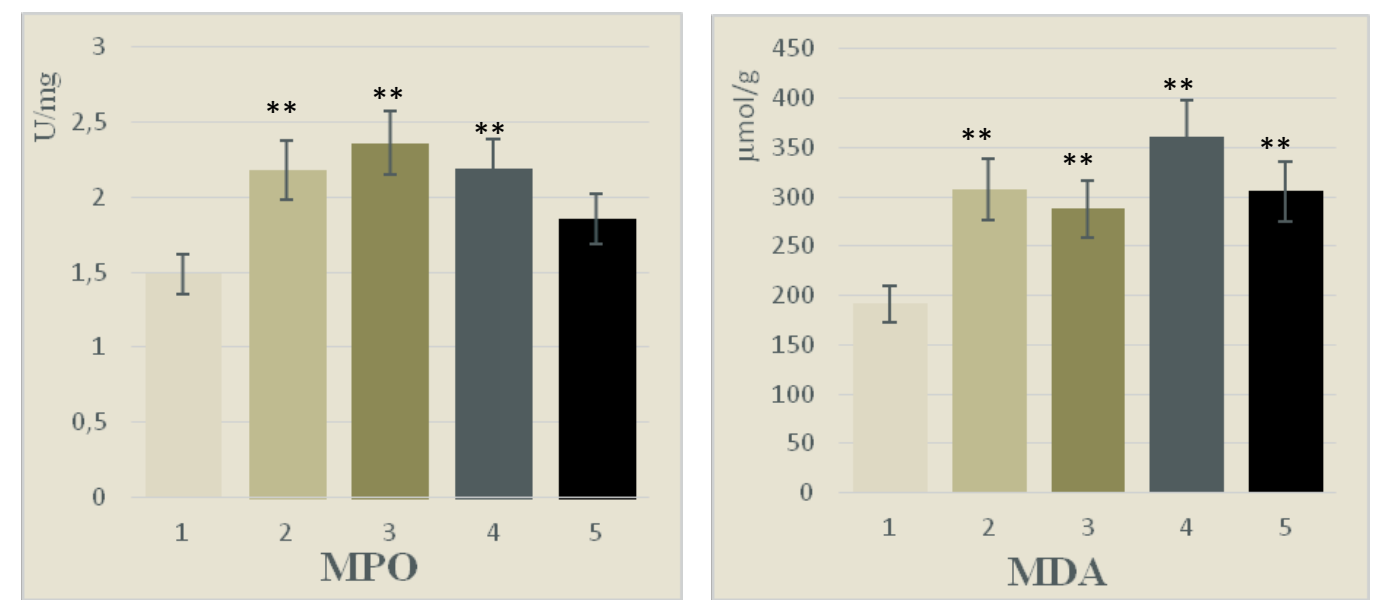

Fig. 3. Activity of MPO and concentration of MDA in homogenates small intestinal mucosa at the background of methotrexate-induced enteropathy of rats of the following groups: group 1 - control group, group 2 - methotrexate-induced enteropathy, group 3 - methotrexate $+1 \mathrm{mg} / \mathrm{kg}$ of NaSH, group 4 - methotrexate $+10 \mathrm{mg} / \mathrm{kg} \mathrm{NaSH}$, group 5 - methotrexate $+\mathrm{L}-\mathrm{Cys}$. Mean $\pm \mathrm{SD}$, $n=8$ in each group of animals. ${ }^{*}-p \leq 0.05,{ }^{* *}-p \leq 0.01$, in relation to control animals. 

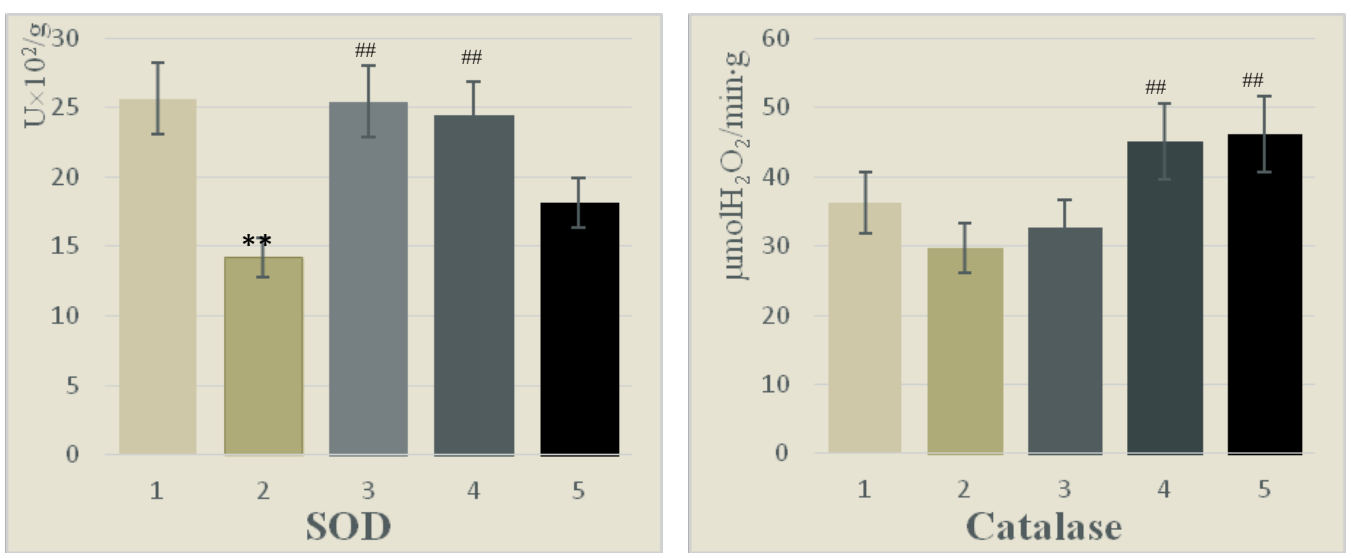

Fig. 4. Activity of SOD and catalase in homogenates small intestinal mucosa at the background of methotrexate-induced enteropathy of rats of the following groups: group 1 - control group, group 2 - methotrexate-induced enteropathy, group 3 methotrexate $+1 \mathrm{mg} / \mathrm{kg}$ of NaSH, group $4-$ methotrexate $+10 \mathrm{mg} / \mathrm{kg} \mathrm{NaSH}$, group 5 - methotrexate+L-Cys. Mean $\pm S D, n=8$ in each group of animals. ${ }^{*}-p \leq 0.05,{ }^{* *}-p \leq 0.01$, in relation to control animals; ${ }^{*}-p \leq 0.05,{ }^{*}-p \leq 0.01$ as compared to the methotrexate action.

crease of MPO activity in small intestine of methotrexate-treated rats (Fig. 3).

It is well known that $\mathrm{H}_{2} \mathrm{~S}$ exhibits strong antioxidant properties. In our study an antioxidant action of $\mathrm{H}_{2} \mathrm{~S}$ inhibitor NaHS was manifested by the increase of SOD activity as compared to methotrexate group (Fig. 4). Surprisingly, L-Cys didn't demonstrate such action. However all studied donors didn't decrease MDA concentration. Catalase activity significantly increased as a result of $10 \mathrm{mg} / \mathrm{kg}$ $\mathrm{NaSH}$ and L-Cys action. (Fig.4)

Thus, although methotrexate is widely used in clinics as an anticancer agent, it's utility is limited by its gastrointestinal toxicity which is one of the most serious side effects in its treatment. However, the mechanism of the toxicity has not been completely clarified [16]. On the other hand, the oxidative stress is known to play an important role in various diseases and drug-induced side effects. In our study the administration of methotrexate induced the development of oxidative stress. On the other hand many studies have suggested an im- portant role of nitric oxide in methotrexate-induced injury [17]. Our results allow us to suggest the potential role of the decrease of endogenous $\mathrm{H}_{2} \mathrm{~S}$ concentration in the mechanisms of methotrexate induced enterotoxicity. Thus, donors of $\mathrm{H}_{2} \mathrm{~S}$ may significantly regulate both oxidative stress and iNOS activation in methotrexate models. NaHS is commonly used in in vivo and in vitro experiments as a source of $\mathrm{H}_{2} \mathrm{~S}$ to study the possible physiologic functions of endogenous $\mathrm{H}_{2} \mathrm{~S}$. NaHS immediately dissociates and forms the hydrosulfide anion $\mathrm{HS}^{-}$, which then reacts with $\mathrm{H}^{+}$to form $\mathrm{H}_{2} \mathrm{~S}$ [18]. In our study NaHS displayed the regulatory effect upon iNOS and SOD activity without any significant effect of MDA concentration and MPO activity.

CONCLUSIONS. Nirtoso-oxidative stress plays the key role in small intestine of rats in mechanisms of enteropathy development resulted in methotrexate administration. $\mathrm{H}_{2} \mathrm{~S}$ donors modulate parameters of NO-synthase system and activity of SOD of methotrexate-treated rats.

\section{LITERATURE}

1. Drug-induced injury in the gastrointestinal tract: clinical and pathologic considerations / M. P. Pusztaszeri, R. M. Genta, B. L. Cryer // Nat. Clin. Pract. Gastroenterol. Hepatol. - 2007. - 4. - P. 442-453.

2. Hydrogen sulfide releasing 2-mercaptoacrylic acid-based derivative possesses cytoprotective activity in a small intestine of rats with medication-induced enteropathy / Y. Sklyarova, I. Fomenko, I. Lozynska [et al.] // Sci. Pharm. - 2017. - 85, No. 4. - P. E35.
3. Jahovic N. Amelioration of methotrexate-induced enteritis by melatonin in rats / N. Jahovic, G. Sener // Cell Biochem. Funct. - 2004. - 22, No. 3. - P. 169-178.

4. Цитопротективна дія донорів гідрогену сульфріду в слизовій оболонці тонкої кишки за індометациніндукованих ентеропатій у щурів / Ю. О. Склярова, Н.В.Денисенко, І. І. Ільків, І. С. Фоменко // Експерим. та клініч. фрізіологія і біохімія. - 2017. - № 1. С. 38-44. 
5. Szabo C. International Union of Basic and Clinical Pharmacology. Cll: Pharmacological Modulation of $\mathrm{H}_{2} \mathrm{~S}$ Levels: $\mathrm{H}_{2} \mathrm{~S}$ Donors and $\mathrm{H}_{2} \mathrm{~S}$ Biosynthesis Inhibitors / C. Szabo, A. Papapetropoulos // Pharmacol. Rev. 2017. - 69, No. 4. - P. 497-564.

6. Dietary modulation of methotrexate-induced enteritis in cats / S. L. Marks, A. K. Cook, S. Griffey [et al.] // Am. J. Vet. Res. - 1997. - 58, No. 9. - P. 989-996.

7. Раваева М. Ю. Изменение активности системы синтеза оксида азота под действием низкоинтенсивного миллиметрового излучения / М. Ю. Раваева, Е. Н. Чуян // Ученые записки Таврического нац. ун-та им. В. И. Вернадского. - 2011. - 24, № 4. - С. 201-210.

8. Green L. C. Analysis of nitrate, nitrite and (1515) nitrate in biological fluids / L. C. Green, A. W. David // Anal. Biochem. - 1982. - 126. - P. 131-138.

9. Bradley P. P. Cellular and extracellular myeloperoxidase in pyogenic inflammation / P. P. Bradley, R. D. Christensen, G. Rothstein // Blood. - 1982. No. 60. - P. 618-622.

10. Тимирбулатов Р. А. Метод повышения интенсивности свободнорадикального окисления липидсодержащих компонентов крови и его диагностическое значение / Р. А. Тимирбулатов, Е. И. Селезнев // Лаб. дело. - 1981. - № 4. - С. 209-211.

11. Чевари С. Определение антиоксидантных параметров крови и их диагностическое значение в пожилом возрасте / С. Чевари, Т. Андял, Я. Штренгер // Лаб. дело. - 1991. - № 10. - С. 9-13.
12. Метод определения активности каталазы / М. А. Королюк, Л. И. Иванова, И. Г. Майорова, В. Е. Токарев // Лаб. дело. - 1988. - № 1. - С. 16-19.

13. Ольховський О. С. Вплив пропаргілгліцину та натрію гідрогенсульсріду на вміст $\mathrm{H}_{2} \mathrm{~S}$ і показники про-антиоксидантної системи в міокарді щурів різного віку / О. С. Ольховський, Н.В.Заічко // Мед. хімія. 2013. - 15, № 4. - P. 10-15.

14. Gemici B. Anti-inflammatory and cytoprotective properties of hydrogen sulfide / B. Gemici, J. L. Wallace // Methods Enzymol. - 2015. - 555. - 169-193.

15. Hydrogen sulfide is an endogenous modulator of leukocyte-mediated inflammation / R. C. Zanardo, V. Brancaleone, E. Distrutti [et al.] // FASEB J. - 2006. 20, No. 12. - 2118-2120.

16. Oxidative stress contributes to methotrexateinduced small intestinal toxicity in rats / Y. Miyazono, F. Gao, T. Horie // Scand J. Gastroenterol. - 2004. - 39, No. 11. - P. 1119-1127.

17. Role of inducible nitric oxide synthase pathway on methotrexate-induced intestinal mucositis in rodents / R. F. Leitão, G. A. Brito, R. B. Oriá [et al]. - BMC Gastroenterol. - 2011. - 11. - P. 90.

18. Carbon monoxide, hydrogen sulfide, and nitric oxide as signaling molecules in the gastrointestinal tract / G. Farrugia, J. H. Szurszewski // Gastroenterology. 2014. - 147, No. 2. - P. 303-313.

\section{REFERENCES}

1. Pusztaszeri, M.P., Genta, R.M., \& Cryer, B.L. (2007). Drug-induced injury in the gastrointestinal tract: clinical and pathologic considerations. Nat. Clin. Pract. Gastroenterol. Hepatol., 4, 442-453.

2. Sklyarova, Y., Fomenko, I., Lozynska, I., Lozynskyi, A., Lesyk, R., \& Sklyarov, A. (2017). Hydrogen sulfide releasing 2-mercaptoacrylic acid-based derivative possesses cytoprotective activity in a small intestine of rats with medication-induced enteropathy. Sci. Pharm, 85(4) E35.

3. Jahovic, N., Sener, G., Cevik, H., Ersoy, Y., Arbak, S., \& Yeğen, B.C. (2004). Amelioration of methotrexate-induced enteritis by melatonin in rats. Cell Biochem. Funct., 22,169-178.

4. Skliarova, U., Denysenko, N., Ilkiv, I., \& Fomenko, I. (2017) Tsytoprotektyvna diia donoriv hidrohenu sulfidu v slyzovii obolontsi tonkoi kyshky za indometatsynenteropatii u shchuriv [Cytoprotective action of donors of hydrogen sulfide in the mucous membrane of the small intestine for indomethacin-induced enteropathy in rats]. Eksperymentalna ta klinichna fiziolohiia ta biokhimiia Experimental and Clinical Physiology and Biochemistry, 77(1), 38-44 [in Ukrainian].

5. Szabo, C., \& Papapetropoulos, A. (2017) International Union of Basic and Clinical Pharmacology. CII: Pharmacological Modulation of $\mathrm{H}_{2} \mathrm{~S}$ Levels: $\mathrm{H}_{2} \mathrm{~S}$ Donors and $\mathrm{H}_{2} \mathrm{~S}$ Biosynthesis Inhibitors. Pharmacol. Rev., 69 (4), 497-564.
6. Marks, S.L., Cook, A.K., Griffey, S., Kass, P.H., \& Rogers, Q.R. (1997). Dietary modulation of methotrexate-induced enteritis in cats. Am. J. Vet. Res., 58 (9), 989-996.

7. Ravayeva, M.Yu., \& Chuyan, E.N. (2011). Izmemenie aktivnosti sistemy oksida azota pod deystviyem nizkointensivnogo izlucheniya [The change in the activity of the nitric oxide synthesis system under the action of low-intensity millimeter radiation]. Uchenye Zapiski Tavricheskogo Natsionalnogo Universiteta im V.I. Vernadskogo. Seriya Biologiya. Khimiya - Scientific Notes of the Tavria National University by V.I. Vernadskyy, 24, 201-210 [in Russian].

8. Green, L.C., Wagner, D.A., Glogowski, J., Skipper, P.L., Wishnok, J.S., \& Tannenbaum, S.R. (1982) Analysis of nitrate, nitrite, and [15N] nitrate in biological fluids. Anal. Biochem., 126 (1),131-138.

9. Bradley, P.P., Christensen, R.D., \& Rothstein, G. (1982). Cellular and extracellular myeloperoxidase in pyrogenic inflammation. Blood, 60 (3), 618-622.

10. Timirbulatov, R.A., \& Seleznev, E.I. (1981) Metod povysheniya intensivnosti svobodnoradikalnogo okisleniya lipidsoderzhashchikh komponentov krovi i ego diagnosticheskoye znacheniye [Method for intensivity increasing free radical oxidation of lipid-containing blood components and its diagnostic value]. Laboratornoye delo - Laboratory Business, 4, 209-117 [in Russian]. 
11. Chevari, S., Andyal, T., \& Shtrenger, Ya. (1991) Opredeleniye antioksidantnykh parametrov krovi i ikh diagnosticheskoye znachenie $v$ pozhylom vozraste [Determination of antioxidant blood parameters and their diagnostic value in the elderly]. Laboratornoye delo Laboratory Business, 10, 9-13 [in Russian].

12. Korolyuk, M., Ivanova, L., Mayorova, I., \& Tokorev, W. (1988). Metod opredeleniya aktivnosti katalazy [Method for the determination of catalase activity]. Laboratornoye delo - Laboratory Work, 1, 16-19 [in Russian].

13. Olkhovskyi, O.S., \& Zaichko, N. (2013). Vplyv proparhllitsynu ta natriiu hidrohen sulfidu na vmist $\mathrm{H}_{2} \mathrm{~S}-\mathrm{i}$ pokaznyky antyoksydantnoi systemy v miokardi shchuriv riznoho viku [Influence of propargylglycine and sodium hydrogen sulfide on $\mathrm{H}_{2} \mathrm{~S}$ content and indicators of proantioxidant system in myocardium of rats of different age] Medychna khimiia - Medical Chemistry, 15 (4), 10-15 [in Ukrainian].
14. Gemici, B., \& Wallace, J.L. (2015). Anti-inflammatory and cytoprotective properties of hydrogen sulfide. Methods Enzymol., 555, 169-193.

15. Zanardo, R.C., Brancaleone, V., Distrutti, E., Fiorucci, S., Cirino, G., \& Wallace, J.L. (2006). Hydrogen sulfide is an endogenous modulator of leukocytemediated inflammation. FASEB J., 20, 12, 2118-2120.

16. Miyazono, Y., Gao, F., \& Horie, T. (2004). Oxidative stress contributes to methotrexate-induced small intestinal toxicity in rats. Scand. J. Gastroenterol., 39 (11), 1119-1127.

17. Leitão, R.F., Brito, G.A., Oriá, R.B., BragaNeto, M.B., Bellaguarda, E.A., Silva, J.V., Gomes, A.S. et al. (2011). Role of inducible nitric oxide synthase pathway on methotrexate-induced intestinal mucositis in rodents. BMC Gastroenterol., 11, 90.

18. Farrugia, G., \& Szurszewski, J.H. (2014). Carbon monoxide, hydrogen sulfide, and nitric oxide as signaling molecules in the gastrointestinal tract. Gastroenterology, 147 (2),303-313.

Ю. О. Склярова, І. С. Фоменко

ЛЬВІВСЬКИЙ НАЦІОНАЛЬНИЙ МЕДИЧНИЙ УНІВЕРСИТЕТ ІМЕНІ ДАНИЛА ГАЛИЦЬКОГО

\section{ВПЛИВ ДОНОРІВ ГІДРОГЕНУ СУЛЬФІДУ НА НІТРОЗО-ОКСИДАТИВНІ ПРОЦЕСИ В ТОНКІЙ КИШЦІ ЩУРІВ ПРИ МЕТОТРЕКСАТІНДУКОВАНІЙ ЕНТЕРОПАТІЇ}

\section{Резюме}

Вступ. Серед чинників, що призводять до розвитку ентеропатій, важливе місце посідають медикаментозні, зумовлені прийманням низки фрармацевтичних препаратів. Зокрема, виражені ентеротоксичні властивості має протипухлинний препарат "Метотрексат". Потенційними чинниками корекції його токсичного впливу могли б бути донори гідрогену сульфріду $\left(\mathrm{H}_{2} \mathrm{~S}\right)$, оскільки біохімічні зміни в тонкій кишці при різних медикаментозних ентеропатіях проявляються зниженням продукування ендогенного $\mathrm{H}_{2} \mathrm{~S}$, що $^{\circ}$ призводить до втрати його цитопротективних властивостей.

Meта дослідження - порівняти вплив донорів $\mathrm{H}_{2} \mathrm{~S}$ на показники NO-синтазної системи та ступінь оксидативного стресу в тонкій кишці щурів на тлі метотрексатіндукованої ентеропатії.

Методи дослідження. Досліди виконували на щурах, яким на тлі ентеротоксичної дії метотрексату вводили донори $\mathrm{H}_{2} \mathrm{~S}$ : NaHS у дозах 1 ma 10 мг/ке, L-цистеїн у дозі 30 мг/ка. У слизовій оболонці тонкої кишки визначали активність синтаз оксиду азоту, мієлопероксидази, супероксиддисмутази і каталази; концентрацію стабільних метаболітів оксиду азоту та ТБК-активних продуктів; у сироватці крові - концентрацію $\mathrm{H}_{2} \mathrm{~S}$.

Результати й обговорення. Введення протипухлинного препарату "Метотрексат", хоч і не спричинювало змін поверхні тонкої кишки, проте призводило до суттєвих біохімічних змін. Зокрема, концентрація оксиду азоту зростала внаслідок активації індуцибельної синтази оксиду азоту (більше ніж у

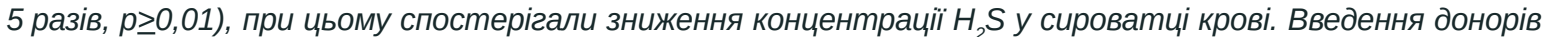
$\mathrm{H}_{2} \mathrm{~S}$ практично повертало чі показники до норми. Метотрексатіндукована ентеропатія зумовлювала

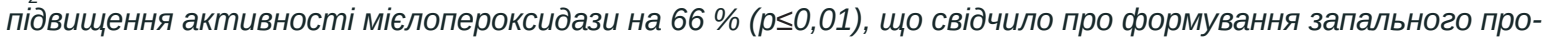
цесу та активацію процесів ліпопероксидації. Введення NaHS не чинило суттєвого впливу на активність мієлопероксидази, проте підвищувало активність супероксиддисмутази, практично повертаючи їі до показників норми.

Висновки. Ключовою біохімічною зміною, що призводить до фрормування ентеропатії при введенні протиракового препарату "Метотрексат", слугує нітрозо-оксидативний стрес. Донори $\mathrm{H}_{2} \mathrm{~S}$ чинять модулюючий вплив на показники NO-синтазної системи та активність супероксиддисмутази.

КЛЮЧОВІ СЛОВА: ентеропатія; метотрексат; гідрогену сульфід; синтази оксиду азоту; оксидативний стрес. 


\section{ВЛИЯНИЕ ДОНОРОВ СЕРОВОДОРОДА НА НИТРОЗО-ОКСИДАТИВНЫЕ ПРОЦЕССЫ В ТОНКОЙ КИШКЕ КРЫС ПРИ МЕТОТРЕКСАТИНДУЦИРОВАННОЙ ЭНТЕРОПАТИИ}

\section{Резюме}

Вступление. Среди фракторов, приводящих к развитию энтеропатий, важное место занимают медикаментозные, обусловленные употреблением ряда фрармацевтических препаратов. В частности, выраженными энтеротоксическими свойствами владеет противоопухолевый препарат "Метотрексат". Потенциальными фракторами коррекции его токсического воздействия могли бы быть доноры сероводорода $\left(\mathrm{H}_{2} \mathrm{~S}\right)$, поскольку биохимические изменения в тонкой кишке при различных медикаментозных энтеропатиях проявляются снижением продуцирования эндогенного $\mathrm{H}_{2} \mathrm{~S}$, что приводит к потере его цитопротективных свойств.

Цель исследования - сравнить влияние доноров $\mathrm{H}_{2} \mathrm{~S}$ на показатели NO-синтазной системы и степень оксидативного стресса в тонкой кишке крыс на фроне метотрексатиндуцированной энтеропатии.

Методы исследования. Опыты выполняли на крысах, которым на фроне энтеротоксического действия метотрексата вводили доноры $\mathrm{H}_{2} \mathrm{~S}$ : NaHS в дозах 1 и 10 мг/ке, L-цистеин в дозе 30 мг/кг. В слизистой оболочке тонкой кишки определяли активность синтаз оксида азота, миелопероксидазы, супероксиддисмутазы и каталазы; концентрацию стабильных метаболитов оксида азота и ТБК-активных продуктов; в сыворотке крови - концентрацию $\mathrm{H}_{2} \mathrm{~S}$.

Результаты и обсуждение. Введение противоопухолевого препарата “Метотрексат”, хотя и не вызывало изменений поверхности тонкой кишки, однако приводило к существенным биохимическим изменениям. В частности, концентрация оксида азота возрастала вследствие активации индуцибельной

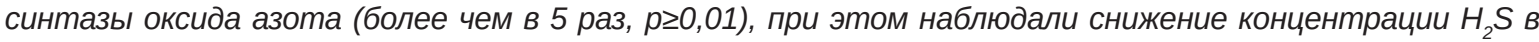
сыворотке крови. Введение доноров $\mathrm{H}_{2} \mathrm{~S}$ практически возвращало эти показатели к норме. Метотрексатиндуцированная энтеропатия обусловливала повышение активности миелопероксидазы на 66 \% ( $p \geq 0,01)$, что свидетельствовало о фрормировании воспалительного процесса и активации процессов липопероксидации. Введение NaHS не оказывало существенного влияния на активность миелопероксидазы, однако повышало активность супероксиддисмутазы, практически возвращая ее к показателям нормы.

Выводы. Ключевым биохимическим изменением, приводящим к фрормированию энтеропатии при введении противоопухолевого препарата "Метотрексат", служит нитрозо-оксидативный стресс. Доноры $\mathrm{H}_{2} \mathrm{~S}$ оказывают модулирующее влияние на показатели NO-синтазной системы и активность супероксидаисмутазы.

КЛЮЧЕВЫЕ СЛОВА: энтеропатия; метотрексат; сероводород; синтазы оксида азота; оксидативный стресс.

Received 12.07.18

Address for correspondence: I. S. Fomenko, Danylo Halytskyi Lviv National Medical University, Pekarska Street, 69, Lviv, 79010, Ukraine, e-mail: iryna.fomenko.Iviv@gmail.com. 